\title{
Changes in phenolic compounds and antioxidant capacity of Andean raspberries in response to Peronospora sparsa
}

\author{
Nathalia Cardona-Hurtado ${ }^{1, *}$, Gloria E. Guerrero Álvarez ${ }^{1}$, Ana M. López Gutiérrez ${ }^{2}$
}

Edited by

Juan Carlos Salcedo-Reyes

(salcedo.juan@javeriana.edu.co)

1. Universidad Tecnológica de Pereira, Faculty of Technology, School of Chemistry, Oleochemistry Research Group, Carrera 27 \# 10-02 Barrio

Álamos, Pereira, Colombia, 660003

2. Universidad Tecnológica de Pereira, Faculty of Environmental Sciences, Biodiversity and Biotechnology Research Group. Carrera 27 \# 10-02 Barrio Álamos, Pereira, Colombia, 660003.

*nathacardona@utp.edu.co

Received: 30-07-2019

Accepted: 26-05-2020

Published on line: 17-08-2020

Citation: Cardona-Hurtado N, Guerrero Álvarez GE, López Gutiérrez AM. Changes in phenolic compounds and antioxidant capacity of Andean raspberries in response to Peronospora sparsa, Universitas Scientiarum, 25 (2): 299-319, 2020. doi: 10.11144/Javeriana.SC25-2.cipc

Funding:

Vicerrectoría de Investigación at Universidad Tecnológica de Pereira.

Electronic supplementary material: N.A.

OPEN ACCESS

\begin{abstract}
In Colombia, the Andean raspberry (Rubus glaucus Benth) is of large economic significance because of its use in industry and widespread consumption as a fresh fruit. However, this crop is highly susceptible to disease by Peronospora sparsa, a fungus that causes between $50 \%$ and $70 \%$ production loss. Plants respond to pathogen-induced damage by increasing the production of specific secondary metabolites, such as phenolic compounds, which have broad industrial applications. This work estimated the antioxidant capacity and phenolic content of healthy and Peronospora sparsa-infected Andean raspberry fruits. Antioxidant capacity was analyzed by DPPH and FRAP methods, while phenolic compounds were analyzed by high performance liquid chromatography coupled to diode array detection (HPLC-DAD). According to the DPPH method, antioxidant capacity increased from $45.9 \pm 1.61 \mu \mathrm{mol} \mathrm{TE} \mathrm{g}{ }^{-1}$ fresh sample in healthy fruits to $67.02 \pm 0.58 \mu \mathrm{mol} \mathrm{TE} \mathrm{g}^{-1}$ fresh sample in affected fruits. The FRAP method revealed an antioxidant response difference from $5.19 \pm 0.8 \mathrm{mmol}$ TE $100 \mathrm{~g}^{-1}$ fresh sample in healthy fruits vs. $10.97 \pm 0.27 \mathrm{mmol}$ TE $100 \mathrm{~g}^{-1}$ fresh sample in affected fruits. The phenolic compound content was observed in a range of $4.14 \pm$ 1.16 to $72.03 \pm 26.68 \mathrm{mg} \mathrm{GAE} \mathrm{L}^{-1}$ for healthy fruits and from $4.48 \pm$ 1.76 to $221.89 \pm 1.18 \mathrm{mg} \mathrm{GAE} \mathrm{L}^{-1}$ for affected fruits. Phenolic acids were the main phenols detected, encompassing derivatives of gallic acid, chlorogenic acid, ferulic acid, ellagic acid, and p-coumaric acid. This work confirmed that the Peronospora sparsa-infected berries contained relatively more antioxidants and phenolic acid compounds than their healthy counterparts, and that this difference was likely due to a defense mechanism to cope with pathogen-induced damage.
\end{abstract}

Keywords: Antioxidants; liquid chromatograph; pathogens; phenolic acids; Rubus glaucus Benth. 


\section{Introduction}

Over the past four years, keen attention has been paid to the use and consumption of metabolites, antioxidants in particular, available in fruits and vegetables and their nutraceutical properties [1]. Fruit shrubs of the genus Rubus are a rich source of such compounds. These are synthesized in small quantities based on the phenological stage of the plant, ecosystem services, and the biotic or abiotic stress it experiences. In general, when pathogenic microorganisms are present, the defense mechanism of the plants is triggered, and the physiological and biochemical process (related to pathogenesis) may lead to protein synthesis. Production of phenolic compounds, deposition of lignin, generation of signaling compounds, and liberation of the reactive species of oxygen are also used to cope with induced stress [2-3].

The Andean raspberry, Rubus glaucus Benth, displays remarkable organoleptic features and is of ample economic significance in Colombian domestic and international markets. It bears diverse phytochemicals including carbohydrates, phenolic compounds, dietary fibers, vitamins, minerals, and volatile compounds [4-6]. Prominent among the Andean raspberry's phenolic compounds are the phenolic acids, e.g., gallic acid and its derivatives, caffeic acid, coumaric acid, ferulic acid derivatives, epicatechin, and ellagic acid derivatives [7]. Flavonols and anthocyanins have also been described in Andean raspberry; the former include quercetin derivatives, glucosides, and glucuronides of quercetin [7-8], and the latter include cyanidin-3-glucoside, cyanidin-3-rutinoside, cyanidin-3-xylosisutinoside, pelargonidin-3 glucoside, and pelargonidin-3-rutinoside [8-9].

In Colombia, Andean raspberry is grown in 19 departments and is considered a competitive fruit. In 2016, an 110453 -ton yield was recorded [10] indicating its economic significance. It is a sought-after fruit because of its attractive color, taste, and the alleged therapeutic value it possesses due to its high concentration of chemical compounds [11]. However, this plant is susceptible to diseases, such as hairy mildew, induced by the Peronospora sp.; grey mold, caused by Botrytis cinereal; powdery mildew, caused by the Oidium sp.; and anthracnose, caused by Colletotrichum sp. [12]. These diseases compromise fruit quality and lead to consumption decline.

In the Colombian departments of Antioquia, Caldas, Risaralda, Santander, Cauca, and Cundinamarca Andean raspberry crops are plagued by downy mildew, which causes a $50 \%$ to $70 \%$ production loss [13]. The affected fruits are regarded as by-products, as this microorganism halts fruit ripening, induces dehydration in the developing fruits, and causes intense 
malformations or dullness of color [12]. Therefore, this study evaluated the chemical response in the fruits, particularly the antioxidant capacity and phenolic compounds synthesized in response to the biotic stress, to determine its potential as a natural source of biologically active compounds with a variety of applications.

\section{Materials and Methods}

\section{Andean raspberry stems and fruits}

The sampling was carried out in the municipalities of Santuario and Santa Rosa de Cabal, in the department of Risaralda (Colombia); the coordinates of the sampling locations are provided in Table 1. Fruits were collected twice per municipality using a fully randomized block design between February and May of 2017. Both healthy and Peronospora sparsa-affected fruits of the same maturity state were sampled. Approximately $500 \mathrm{~g}$ of each plant material were taken by crop.

The characteristic downy mildew symptoms were identified in the field and a morphological characterization of the fungus was subsequently conducted in the laboratory. Approximately 10 stems per crop were sampled and transferred to the laboratory for further analysis. Portions of berry stems with signs of downy mildew were inspected under a light microscope. Next, the samples were dried with $\mathrm{CO}_{2}$ in a critical point desiccator (Sandri-780A, USA) for $40 \mathrm{~min}$ and placed in a copper sample holder and coated with gold in an ionizer (Ion Sputter JFC-1100, JEOL, Japan) for 1 min. Finally, the preparations were observed and photographed in a scanning electron microscope, FEI model Quanta 250 (Thermo Fisher Scientific, Japan) as described by Cardona-Hurtado et al. [14], and the structures observed were compared with those reported by Fierro-Corrales et al. [15].

Healthy Andean raspberry fruits and those affected by Peronospora sparsa, at maturity stages 5 and 6 (based on the NTC 4106 classification; ICONTEC, 1997) were collected in polyethylene bags. These were then packed in coolers at $4^{\circ} \mathrm{C}$ and transported from the sampling site to the Technological University of Pereira. They were then stored until further analysis at $-70^{\circ} \mathrm{C}$.

\section{Extract collection from ripe berries}

First, the harvested berries were passed through a mill; subsequently, the plant material (sorted by healthy and affected fruits) was weighed by collection site and in triplicate. The extracts were collected using acid hydrolysis with $80 \%$ ethanol. The $\mathrm{pH}$ was adjusted to 2.6 by adding 
Table 1. Location of the sampled Andean raspberry (Rubus glaucus Benth) fields.

\begin{tabular}{|c|c|c|c|}
\hline Municipality & $\begin{array}{l}\text { Sampling } \\
\text { site }\end{array}$ & Coordinates & Altitude (m) \\
\hline \multirow{4}{*}{$\begin{array}{c}\text { Santa Rosa } \\
\text { de Cabal }\end{array}$} & \multirow{2}{*}{1} & N $04^{\circ} 52^{\prime} 37.2^{\prime \prime}$ & \multirow{2}{*}{$2244 \pm 4$} \\
\hline & & W $075^{\circ} 32^{\prime} 31.1^{\prime \prime}$ & \\
\hline & \multirow{2}{*}{2} & N $04^{\circ} 53^{\prime} 24.1^{\prime \prime}$ & \multirow{2}{*}{$2085 \pm 3$} \\
\hline & & W $075^{\circ} 33^{\prime} 44^{\prime \prime}$ & \\
\hline \multirow{4}{*}{ Santuario } & \multirow{2}{*}{3} & N 05 $07^{\prime} 25.2^{\prime \prime}$ & \multirow{2}{*}{$2114 \pm 3$} \\
\hline & & W 076 00’ 01.2” & \\
\hline & \multirow{2}{*}{4} & N 05 $06^{\prime} 45.0^{\prime \prime}$ & \multirow{2}{*}{$2120 \pm 3$} \\
\hline & & W 075'59' 54.9" & \\
\hline
\end{tabular}

citric acid, according to Guzmán-Nieves [17]. Each sample was mixed with the solvent in a ratio of 1:8 via mechanical orbital shaking (Thermo Fisher Scientific MaxQ 4450, Canada) at $250 \mathrm{rpm}$ for $2 \mathrm{~h}$ at room temperature, following Velićanski et al. [18] and Abu-Bakar et al. [19].

The derived extracts were filtered to remove any solid fruit particles and their $\mathrm{pH}$ was adjusted by adding ethanol to $10 \mathrm{~mL}$. Next, the phenolic acids were extracted three times, using ethyl acetate in a ratio of $1: 1$ of crude extract to solvent extract at a working pressure and temperature of $84.9 \mathrm{kPa}$ and $21^{\circ} \mathrm{C}[20]$. Finally, the samples were concentrated under vacuum (Heidolph Laborota 4001, Germany), and the residual solvent was removed via nitrogen flow. The extracts were then stored at $4^{\circ} \mathrm{C}$ until further analysis.

\section{Evaluation of antioxidant capacity}

The spectrophotometric method with DPPH (2, 2-diphenyl-1-picrilhydrazyl) was used for antioxidant capacity evaluation implementing the modified methodology by Ortiz et al. [4]. Using a microplate spectrophotometer (Thermo Scientific, Multiskan GO, Japan), $10 \mu \mathrm{L}$ of the extract (diluted earlier in the ratio of DF: 20) were mixed with $200 \mu \mathrm{L}$ of the ethanolic DPPH solution at $50.7 \mu \mathrm{M}\left(20 \mathrm{mg} \mathrm{L}^{-1}\right)$. After incubating this mixture for $30 \mathrm{~min}$, its 
absorbance was measured at $517 \mathrm{~nm}$. Then a calibration curve was made with Trolox as the reference standard. The results were expressed as micromoles of the Trolox Equivalents per gram of fresh sample weight ( $\mu \mathrm{Mol} \mathrm{TE} \mathrm{g}^{-1}$ fresh sample).

The FRAP (Ferric Reducing Antioxidant Power Assay) analysis was conducted following Calderón-Oliver et al. [21]. The FRAP reagent was prepared mixing a $300 \mathrm{mM}$ acetate buffer solution ( $\mathrm{pH} 3.6$ ) with $10 \mathrm{mM}$ TPTZ, $40 \mathrm{mM} \mathrm{HCl}$, and $20 \mathrm{mM} \mathrm{FeCl}_{3}$ solution (10:1:1). Using a microplate spectrophotometer, $150 \mu \mathrm{L}$ of the FRAP were mixed with $20 \mu \mathrm{L}$ of extract (diluted earlier in a ratio of DF: 20). After incubating this mixture for $30 \mathrm{~min}$, the absorbance was measured at $593 \mathrm{~nm}$. Then, a calibration curve was used with Trolox as the reference standard. Results were expressed in milligrams of Trolox Equivalents per $100 \mathrm{~g}$ of extract (mmol TE $100 \mathrm{~g}^{-1}$ fresh sample).

\section{Evaluation of phenolic compounds by HPLC-DAD}

The presence of phenolic compounds was assessed via High Performance Liquid Chromatography with diode array (HPLC-DAD), following the modified protocol by Estupiñan et al. [22]. This involved using a high efficiency liquid chromatography system (Jasco HPLC 2000 Plus, Japan), which possessed a quaternary gradient pump (Jasco PU-2089 Plus, Japan), autosampler (Jasco AS-2059 Plus, Japan), column oven, and a diode array detector (Jasco MD-2015 Plus, Japan). The system was controlled by the EZChrom Elite software.

The separation was done employing an ODS2 column (Spherisil $250 \mathrm{~mm} \times$ $4.6 \mathrm{~mm} \mathrm{ID} \times 5 \mu \mathrm{m}$ ), a precolumn (Spherisil $5 \mathrm{~mm} \times 4.6 \mathrm{~mm} \mathrm{ID} \times 5 \mu \mathrm{m}$ ), and an elution system either using $5 \%$ formic acid in water (Solvent A) or $5 \%$ formic acid in acetonitrile (Solvent B). A linear gradient was implemented, beginning with $5 \%$ Solvent $\mathrm{B}$, and increasing its concentration to $15 \%, 19 \%$, and $20 \%$ at 15, 17 and $25 \mathrm{~min}$, respectively. The analysis run was performed with solvent $\mathrm{B}$ at $20 \%$ for 30 minutes. The column was maintained at $25^{\circ} \mathrm{C}$, at a flow rate of $1 \mathrm{~mL} \mathrm{~min}^{-1}$. An injection volume of $20 \mu \mathrm{L}$ was utilized, and data were recorded between 200 and $700 \mathrm{~nm}$.

\section{Qualitative analysis of phenolic acid}

Preliminary phenolic acid identification was performed contrasting the retention times of the following reference standards: $100 \%$ gallic acid, $99.63 \%$ protocatechuic acid, $95 \%$ chlorogenic acid, $95 \%$ syringic acid, $98 \%$ p-coumaric acid, and $100 \%$ ferulic acid, Sigma-Aldrich. These standards were assessed under conditions identical to those of the HPLC-DAD analysis 
(see preceding section). Furthermore, the absorbance maxima of the peaks were determined based on the corresponding ultraviolet spectrum of the standards and the samples evaluated. To identify the compounds that were not determined by their retention times, the absorbance maxima of the samples were compared with those reported for phenolic compounds [23]. The amount of the identified compounds was inferred relative to that of gallic acid ( $\geq 95 \%$ ), as an external reference compound. The quantities were expressed in milligrams of gallic acid equivalents per liter of sample (mg GAE $\left.\mathrm{L}^{-1}\right)$.

\section{Statistical analysis}

The results were expressed as mean \pm standard deviation and were obtained in triplicate for each of the samples from the two municipalities. The triplicates corresponded to independent extractions from each of the samples. An analysis of variance (ANOVA) was conducted using IBM SPSS Statistics Version 22 software, followed by the Tukey test. $\mathrm{P}$ values of $<0.05$ were indicative of statistically significant differences between the amount the phenolic compounds and antioxidant capacity of healthy and affected berries. The relation between phenolic acids and the antioxidant capacity determined using the DPPH and FRAP methods were analyzed using Pearson's correlation.

\section{Results}

The antioxidant capacities of the extracts from ripe healthy and infected Andean raspberry fruits grown in the department of Risaralda, measured by DPPH and FRAP methods, are shown in Table 2.

The statistical analysis on antioxidant capacities revealed significant differences $(\mathrm{p}<0.05)$ between healthy and Peronospora sparsa-infected berries. However, no difference was noted between sampling sites, implying that the antioxidant capacities of Andean raspberries cultivated throughout the department of Risaralda are chiefly dependent on their Peronospora sparsa infection status; namely, more antioxidant content was detected in affected fruits than in healthy ones. The fruits affected by Peronospora sparsa had antioxidant capacities surpassing those of healthy fruits by up to $50 \% ; 45.9 \pm$ 1.61 vs $67.02 \pm 0.58 \mu \mathrm{mol} \mathrm{TE} \mathrm{g}{ }^{-1}$ of fresh sample, in healthy and affected fruits, respectively, and $5.19 \pm 0.8$ vs. $10.97 \pm 0.27 \mathrm{mmol} \mathrm{TE} 100 \mathrm{~g}^{-1}$ of fresh sample, in healthy and affected fruits, respectively, according to the DPPH and FRAP methods (Table 2). 
Table 2. Antioxidant capacity of the Andean raspberry (Rubus glaucus Benth) extracts, cultivated in the department of Risaralda, measured by the DPPH and FRAP methods. The different letters of $a, b, c, d$, and e indicate significant differences for each method $(p<0.05)$ TE: Trolox Equivalents, $\mathrm{N}=3$.

\section{ANTIOXIDANT CAPACITY}

\begin{tabular}{|c|c|c|c|c|}
\hline \multirow{2}{*}{$\underset{\text { site }}{\text { Sampling }}$} & \multicolumn{2}{|c|}{ DPPH ( $\mu \mathrm{mol} \mathrm{TE} \mathrm{g}^{-1}$ fresh sample) } & \multicolumn{2}{|c|}{ FRAP (mmol TE $100 \mathrm{~g}^{-1}$ fresh sample) } \\
\hline & $\begin{array}{l}\text { Healthy } \\
\text { fruits }^{b}\end{array}$ & $\begin{array}{l}\text { Affected } \\
\text { fruits }^{\mathrm{c}}\end{array}$ & $\begin{array}{l}\text { Healthy } \\
\text { fruits }^{\mathrm{d}}\end{array}$ & $\begin{array}{l}\text { Affected } \\
\text { fruits }^{\text {e }}\end{array}$ \\
\hline $1^{\mathrm{a}}$ & $53.70 \pm 1.47$ & $64.07 \pm 0.97$ & $3.76 \pm 0.05$ & $5.19 \pm 0.80$ \\
\hline $2^{a}$ & $40.41 \pm 3.38$ & $63.94 \pm 1.79$ & $7.40 \pm 0.02$ & $8.64 \pm 0.30$ \\
\hline $3^{a}$ & $52.73 \pm 2.53$ & $67.02 \pm 0.58$ & $8.74 \pm 0.15$ & $10.97 \pm 0.27$ \\
\hline $4^{a}$ & $35.53 \pm 0.49$ & $45.94 \pm 1.61$ & $3.49 \pm 0.03$ & $5.24 \pm 0.10$ \\
\hline
\end{tabular}

The chromatographic profiles shown in Fig. 1 revealed seven peaks that were likely to correspond to phenolic compounds. The absorbance maxima of these compounds were between $255 \mathrm{~nm}$ to $312 \mathrm{~nm}$ (Table 3); however, it was not possible determine the identity of these compounds because their retention time did not coincide with the retention time of the standards used. Only compounds four, five, six, and seven were q uantifiable. The concentrations of phenolic acids (Table 3 ) were found in a range between $4.14 \pm 1.16$ to $72.03 \pm 26.68 \mathrm{mg} \mathrm{GAE} \mathrm{L}^{-1}$ in healthy fruits and between $4.48 \pm 1.76$ to $221.89 \pm 1.18 \mathrm{mg} \mathrm{GAE} \mathrm{L}^{-1}$ in affected fruits.

Correlations between antioxidant capacities and phenolic acid content were performed to gain insight into the oxidative mechanisms in the evaluated samples. The antioxidant capacity measured by DPPH and phenolic acid content in healthy and affected ripe fruits were of $29 \%$ and $46 \%$, respectively. Antioxidant capacity, measured by FRAP, exhibited correlations with phenolic content in healthy and affected fruits of $90 \%$ and $94 \%$, respectively (Fig. 2).

\section{Discussion}

One of the main characteristics of the Rubus genus is its antioxidant activity. This is elicited by the action phenolic compounds, and by an ability to remove free radicals. Concerning phenolic acids, antioxidant activity is dependent upon the number of hydroxyl groups and their locations in relation to the functional carbonyl group [24]. 
Table 3. Maximum absorbance, quantification, a $\mathrm{nd}$ re tention $\mathrm{t}$ i mes of the compounds (peaks) present in Andean raspberry (Rubus glaucus Benth) extracts. The maximum absorbance, retention times, and names of the standard compounds are also provided. -: Not quantifiable 1, 2, 3 a nd 4: Sampling sites in the department of Risaralda.

\begin{tabular}{|c|c|c|c|c|c|c|c|c|}
\hline \multicolumn{2}{|l|}{ Peak } & 1 & 2 & 3 & 4 & 5 & 6 & 7 \\
\hline \multicolumn{2}{|c|}{ Retention time $\left(t_{R}\right)$} & 4.05 & 4.32 & 6.19 & 17.39 & 22.75 & 23.1 & 24.36 \\
\hline \multicolumn{2}{|c|}{$\begin{array}{c}\text { Maximum } \\
\text { absorbance (nm) }\end{array}$} & 271 & $227-260$ & 252 & 255 & 354 & 352 & 355 \\
\hline \multirow{4}{*}{$\begin{array}{l}\text { Healthy fruits } \\
\text { concentration } \\
\left(\text { mg GAE } L^{-1}\right)\end{array}$} & 1 & - & - & - & $17.68 \pm 7.60$ & - & $4.90 \pm 3.25$ & $6.75 \pm 5.03$ \\
\hline & 2 & - & - & - & $46.75 \pm 1.09$ & - & $4.14 \pm 1.16$ & - \\
\hline & 3 & - & - & - & $72.03 \pm 26.68$ & - & $5.17 \pm 1.14$ & $10.27 \pm 2.46$ \\
\hline & 4 & - & - & - & $12.73 \pm 3.15$ & - & - & - \\
\hline \multirow{4}{*}{$\begin{array}{l}\text { Affected fruits } \\
\text { concentration } \\
\left(\text { mg GAE } L^{-1}\right)\end{array}$} & 1 & - & - & - & $46.10 \pm 15.39$ & $4.87 \pm 1.26$ & $6.21 \pm 1.18$ & $7.48 \pm 0.82$ \\
\hline & 2 & - & - & - & $116.13 \pm 1.43$ & $8.10 \pm 0.20$ & $11.92 \pm 0.63$ & $10.36 \pm 0.40$ \\
\hline & 3 & - & - & - & $221.89 \pm 1.18$ & $19.64 \pm 0.80$ & $25.76 \pm 0.84$ & $32.91 \pm 1.81$ \\
\hline & 4 & - & - & - & $14.86 \pm 4.64$ & $4.48 \pm 1.76$ & $6.14 \pm 1.88$ & $8.42 \pm 4.42$ \\
\hline \multicolumn{9}{|c|}{ Standard Mix } \\
\hline \multicolumn{3}{|l|}{ Peak } & 1 & 2 & 3 & 4 & 5 & 6 \\
\hline \multicolumn{3}{|c|}{ Retention time (tR) } & 4.04 & 6.64 & 12.29 & 15.81 & 19.76 & 22.61 \\
\hline \multicolumn{3}{|c|}{$\begin{array}{l}\text { Maximum absorbance } \\
(\mathrm{nm})\end{array}$} & 270 & $257-289$ & $248-323$ & 273 & 306 & $247-320$ \\
\hline \multicolumn{3}{|c|}{ Compound name } & $\begin{array}{l}\text { Gallic } \\
\text { acid }\end{array}$ & $\begin{array}{l}\text { Protocatechuic } \\
\text { acid }\end{array}$ & $\begin{array}{l}\text { Chlorogenic } \\
\text { acid }\end{array}$ & $\begin{array}{c}\text { Syringic } \\
\text { acid }\end{array}$ & $\begin{array}{l}\text { p-coumaric } \\
\text { acid }\end{array}$ & $\begin{array}{l}\text { Ferulic } \\
\text { acid }\end{array}$ \\
\hline
\end{tabular}

To assess the antioxidant activity in Andean raspberry fruits, two methods (DPPH and FRAP) were employed. The DPPH method involves the reduction of the DPPH radical; this provides a rate to estimate the ability of a compound to capture radicals [25], and is based on an electron transfer reaction or hydrogen-atom abstraction as a marginal reaction pathway [26]. The FRAP method measures the ability of the compounds to reduce ferric 2,4,6-tripyridyl-s-triazine (TPTZ) by electron transfer [26-27]. 

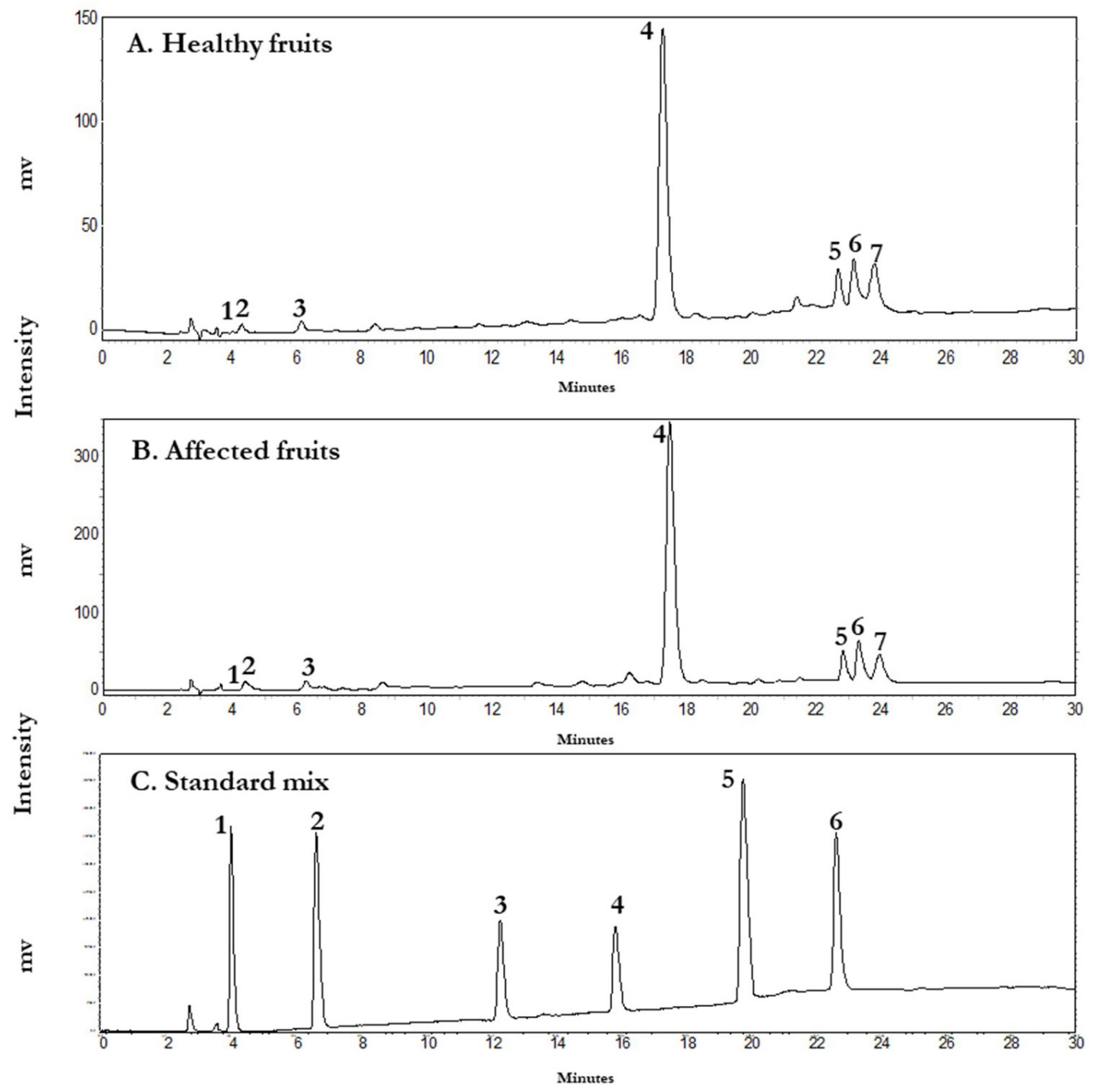

Figure 1. Chromatographic separation of the extracts drawn from the samples of ripe fruits of Andean raspberry (Rubus glaucus Benth) fruits affected and unaffected by Peronospora sparsa. Only one profile is displayed for each plant sample, as no significant differences ( $\mathrm{p}>0.05)$ were observed among sampling locations.

The antioxidant capacities of healthy Andean raspberry fruits assessed by the DPPH and FRAP methods was found in a range between $35.53 \pm 0.49$ to


fresh samples, respectively. Compared to other studies carried for the same species using the DPPH method, the values were within ranges reported by Vasco et al. [28] and Bernal et al. [29], with values around to $33.29 \pm 5.56$ and $41 \pm 16 \mu \mathrm{mol} \mathrm{TE}{ }^{-1}$ for the fresh samples, respectively. However, our values surpass those reported by Wang and Lin [30] and Sellappan et al. [31] for other raspberry species, such as Rubus fructicosus and Rubus idaeus. 
Healthy fruits
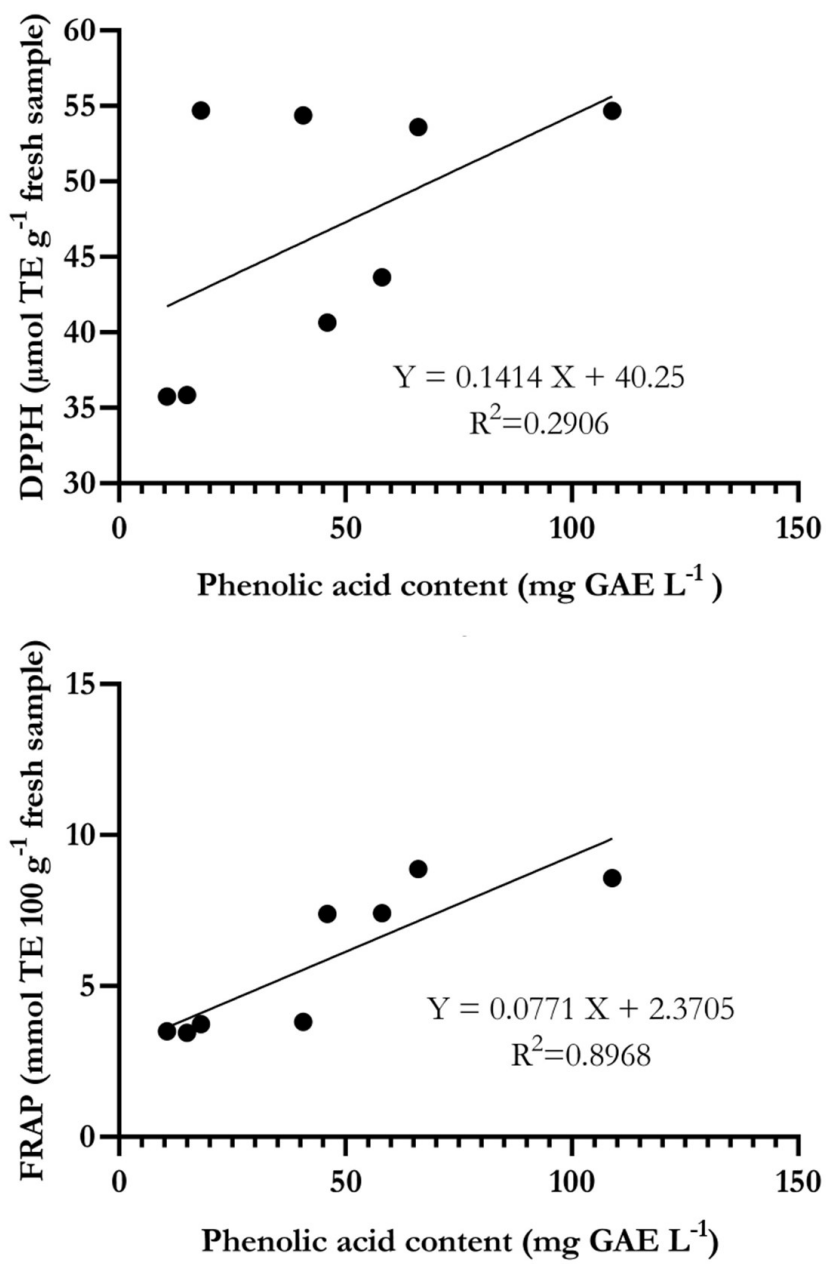

Affected fruits
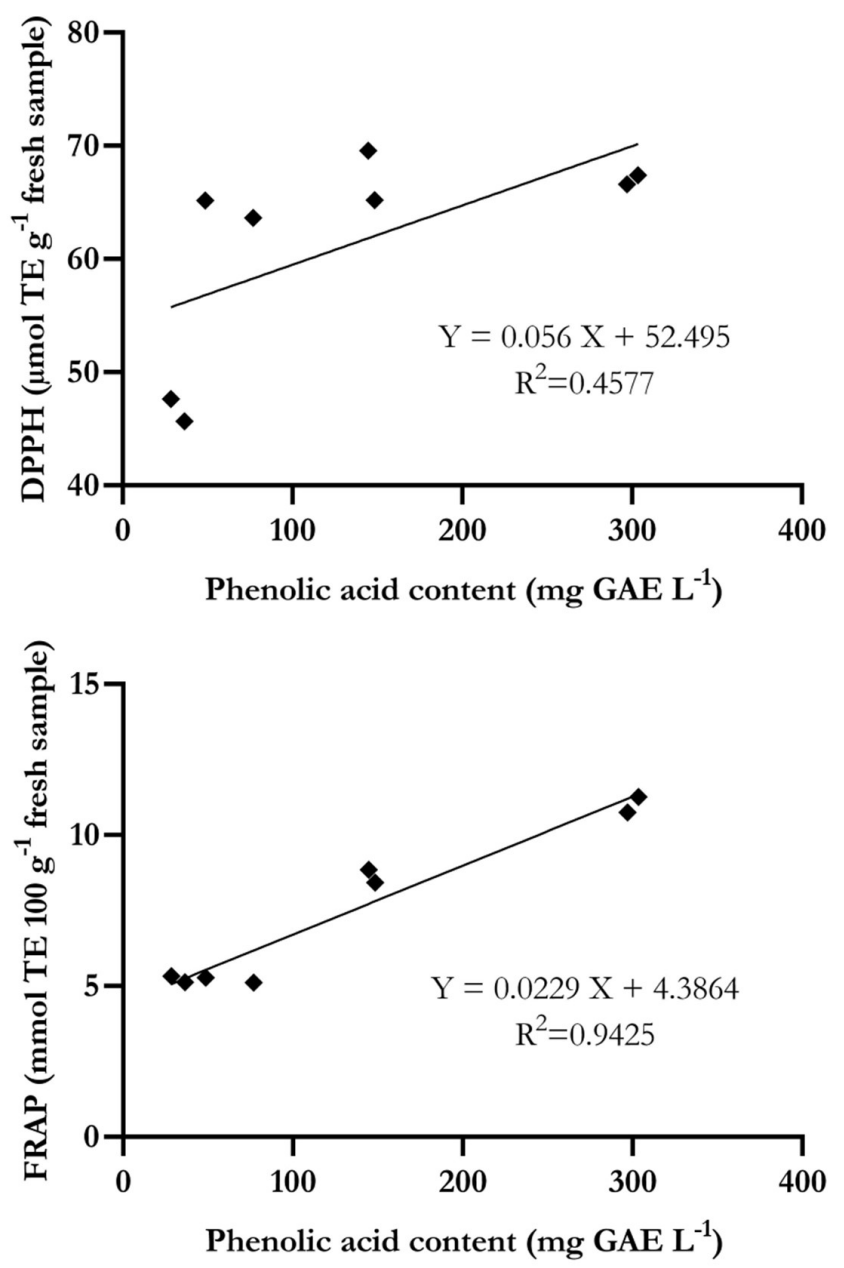

Figure 2. Correlation between phenolic acid content and antioxidant capacity of healthy and affected fruits measured by DPPH and FRAP methods.

Concerning the results obtained by the FRAP method, the antioxidant capacities for healthy Andean raspberry fruits were similar to those reported by Garzón et al. [32] and Vasco et al. [28], with values around to 4.5 and $6 \mathrm{mmol}$ TE $100 \mathrm{~g}^{-1}$ for the fresh samples. Furthermore, this method also revealed a higher antioxidant capacity of Andean raspberry fruits affected by Peronospora sparsa.

This higher antioxidant capacity of infected berried could be due to phenolic compounds being accumulated by the plant as a defense mechanism against Peronospora sparsa [33]. These compounds offer strong protection against hostile factors. Based on the above facts, healthy plants contain these compounds in low concentrations. However, in infected plants these levels 
show substantial increases to cope with the pathogenic invasion, as revealed in the synthesis of chlorogenic, caffeic, and ferulic acids, which are the types of phenolic compounds the plants accumulate as defense substances against fungal infections [34]. Mikulic-Petkovsek et al. [35] reported a higher concentration of phenolic content in Rubus idaeus infected tissue, observing values of $8566 \pm 721 \mathrm{mg} \mathrm{kg}^{-1}$ fresh weight for healthy tissue and of $21699 \pm$ $1310 \mathrm{mg} \mathrm{kg}^{-1}$ fresh weight for infected tissue.

A maximum of seven compounds were present in healthy and affected Andean raspberry fruits (Fig. 1). These compounds were found in higher concentration in extracts from berries affected by Peronospora sparsa. According to their UV-Vis spectra, these compounds are likely phenolic acids with $255 \mathrm{~nm}$ to $312 \mathrm{~nm}$ absorbance maxima (Table 3). The comparison of the observed retention times and ultraviolet profiles of these compounds in the literature facilitated the recognition of their phenolic acid nature, which from prior studies conducted in Andean raspberry are likely derivatives of gallic acid, such as methyl gallate, ethyl gallate, propyl gallate [36]; chlorogenic acid; ferulic acid and its derivatives, ellagic acid and p-coumaric acid; as well as its derivatives such as p-cumaroyldopamine [7].

In the assessed Andean raspberry fruits, the phenolic acid concentration, estimated by HPLC, showed a strong correlation with the antioxidant capacity, assessed by the FRAP method. In contrast, the antioxidant capacity of the same berries, estimated by the DPPH method, showed little correlation with their phenolic acid content. Many studies have shown a high correlation between phenols and FRAP-based antioxidant assessments, given the hydrophilic nature of phenolic compounds. But there was a relatively low correlation with the elimination of radicals [37]. The correlation between FRAP and phenolic acids describes approximately $90 \%$ of the oxidative phenomenon. Thus, it can be established that these compounds present in Andean raspberry are good antioxidant, performing their roles as reducing agents that react primarily through an electron transfer mechanism [38].

The antioxidant capacity of the Rubus species is mainly attributed to phenolic compounds which exhibit higher antioxidant power than carotenoids and $\mathrm{E}$ and $\mathrm{C}$ vitamins [39]. Chiefly phenolic acids were present in ripe Andean raspberry fruits affected by Peronospora sparsa. Finally, this work confirmed that the Peronospora sparsa-infected berries contained a relatively higher percentage of phenolic acid compounds than their healthy counterparts and that this difference was likely due to a defense mechanism to cope with pathogen-induced damage. Furthermore, these compounds possess valuable pharmacological, medicinal, and cosmetic properties [39]. 


\section{Conclusion}

This study demonstrated that the amount of the phenolic acids in Andean raspberry (Rubus glaucus Benth) fruits was affected by Peronospora sparsa, showing an increase from $72.03 \pm 26.68 \mathrm{mg} \mathrm{AGE} \mathrm{L}^{-1}$ in healthy fruits to $221.89 \pm 1.18 \mathrm{mg} \mathrm{GAE} \mathrm{L}^{-1}$ in affected fruits. This high phenolic content is directly correlated with the antioxidant capacity of the berries, evaluated by the DPPH and FRAP methods. Antioxidant capacity presented an increase from $45.9 \pm 1.61 \mu \mathrm{mol} \mathrm{TE} \mathrm{g}{ }^{-1}$ fresh sample for healthy fruits to $67.02 \pm$ $0.58 \mu \mathrm{mol} \mathrm{TE}^{-1}$ fresh sample for affected fruits, according to the DPPH method, and from $5.19 \pm 0.8 \mathrm{mmol} \mathrm{TE} 100 \mathrm{~g}^{-1}$ fresh sample for healthy fruits to $10.97 \pm 0.27 \mathrm{mmol} \mathrm{TE} 100 \mathrm{~g}^{-1}$ fresh sample for affected fruits, with the FRAP method. Andean raspberry (Rubus glaucus Benth) crops are highly susceptible to attack by Peronospora sparsa, causing between $50 \%$ and $70 \%$ of production loss, with affected fruits being discarded as by-products. However, our results provide a new usage possibility of downy mildew-affected berries because of their high antioxidant capacity.

\section{Acknowledgments}

The authors acknowledge the Vicerrectoría de Investigación at Universidad Tecnológica de Pereira for financing this work via the program "Development of scientific and technological capabilities in biotechnology applied to the health and agro-industry sectors, in the department of Risaralda", which is funded by the National CTeI Fund of the General Royalty System (Code: BPIN 201200010050).

\section{Conflict of interest}

The authors declare having no conflict of interest.

\section{References}

[1] Varzakas T, Zakynthinos G, Verpoort F. Plant food residues as a source of nutraceuticals and functional foods. Foods (Basel, Switzerland), 5 (4): E88, 2016.

doi: $10.3390 /$ foods 5040088

[2] Farahani AS, Taghavi M. Effects of bacterial populations, temperature, and exogenous hydrogen peroxide on the induction of the hypersensitive response in Nicotiana tabacum against Xanthomonas perforans. Journal of Plant Protection Research, 57 (2): 1-4, 2017.

doi: 10.1515/jppr-2017-0019 
[3] Tran NT, Tran TTH, Do ND, Mai VC. The accumulation of SA- and JA-signaling pathways in the response of Glycine max cv. "Nam Dan" to infestation by Aphis craccivora. Journal of Plant Protection Research, 57 (4): 327-330, 2018.

doi: 10.1515/JPPR-2017-0043

[4] Ortiz J, Marín-Arroyo MR, Noriega-Domínguez MJ, Navarro M, Arozarena, I. Color, phenolics, and antioxidant activity of blackberry (Rubus glaucus Benth.), blueberry (Vaccinium floribundum Kunth.), and apple wines from Ecuador. Journal of Food Science, 78 (7): C985-C993, 2013.

doi: 10.1111/1750-3841.12148

[5] Carrillo-Perdomo E, Aller A, Cruz-Quintana SM, Giampieri F, Álvarez-Suarez JM, Riera ME, Riobamba R. Andean berries from Ecuador: A review on Botany, Agronomy, Chemistry and Health Potential. Journal of Berry Research, 5: 49-69, 2015.

doi: $10.3233 / J B R-140093$

[6] Horvitz S, Chanaguano D, Arozarena, I. Andean blackberries (Rubus glaucus Benth) quality as affected by harvest maturity and storage conditions. Scientia Horticulturae, 226: 293-301, 2017.

doi: $10.1016 /$ j.scienta.2017.09.002

[7] Mertz C, Cheynier V, Günata Z, Brat P. Analysis of phenolic compounds in two blackberry species (Rubus glaucus and Rubus adenotrichus) by high-performance liquid chromatography with diode array detection and electrospray ion trap mass spectrometry. Journal of Agricultural and Food Chemistry, 55 (21): 8616-8624, 2007.

doi: $10.1021 /$ jf071475d

[8] Lee J, Dossett M, Finn CE. Rubus fruit phenolic research: The good, the bad, and the confusing. Food Chemistry, 130 (4): 785$796,2012$.

doi: 10.1016/j.foodchem.2011.08.022

[9] Osorio C, Hurtado N, Dawid C, Hofmann T, Heredia-Mira FJ, Morales AL. Chemical characterization of anthocyanins in tamarillo (Solanum betaceum Cav.) and Andes berry (Rubus glaucus Benth.) fruits. Food Chemistry, 132 (4): 1915-1921, 2012.

doi: 10.1016/j.foodchem.2011.12.026 
[10] Agronet, "Estadísticas”, 2017. Retrieved from:

https: / / www.agronet.gov.co/estadistica/Paginas/home. aspx, $\% 202017$

[11] Cerón IX, Higuita JC, Cardona CA. Design and analysis of antioxidant compounds from Andes Berry fruits (Rubus glaucus Benth) using an enhanced-fluidity liquid extraction process with CO2 and ethanol. The Journal of Supercritical Fluids, 62: 96-101, 2012.

doi: 10.1016/j.supflu.2011.12.007

[12] Hincapié-Echeverri OD, Saldarriaga-Cardona A, Díaz-Díez C. Biological, botanical and chemical alternatives for the control of blackberry (Rubus glaucus Benth) diseases. Revista Facultad Nacional de Agronomia, 70 (2): 8169-8176, 2017.

doi: $10.15446 /$ rfna.v70n2.64521

[13] Rodríguez-Díaz KJ, Silva-Rojas HV, Boyzo-Marin J, SeguraLedesma SD, Leyva-Mir SG, Rebollar-Alviter Á. Molecular detection of Peronospora sparsa in sources of primary inoculum and components of resistance in wild blackberry species. European Journal of Plant Pathology, 149 (4): 845-851, 2017.

doi: 10.1007/s10658-017-1232-7

[14] Cardona-Hurtado N, Guerrero-Álvarez GE, López-Gutiérrez AM. Identificación de Peronospora sparsa y evaluación del contenido de fenoles en frutos de mora de castilla afectados por este microrganismo. Revista Ceres, 66 (1): 11-17, 2019.

doi: 10.1590/0034-737x201966010002

[15] Fierro-Corrales D, Apodaca-Sánchez MA, QuinteroBenítez JA, Leyva-Mir SG, Flores-Sánchez JL, Tovar-Pedraza JM. Morphological characterization and histopathology of Peronospora ciceris in chickpea (Cicer arietinum L.) leaves and seeds. Revista Chapingo Serie Horticultura, XXI (1): 81-92, 2015.

doi: 10.5154/r.rchsh.2014.02.010

[16] ICONTEC, "NTC 4106. Frutas Frescas. Mora de Castilla. Especificaciones," Bogotá, 1997. 
[17] Guzmán-Nieves CA. Proceso de obtención de un extracto de compuestos fenólicos a partir de orujo de uva tinta Vitis vinifera a bajas temperaturas para aplicación en alimentos y bebidas destinados a consumo humano y animal, México, WO2011062468A2, clasificación A23L33/105, 24 de junio 2011.

https://patents.google.com/patent/WO2011062468A2/es

[18] Velićanski AS, Cvetković DD, Markov SL. Screening of antibacterial activity of raspberry (Rubus idaeus L.) fruit and pomace extracts. Acta Periodica Technologica, 43 (43): 305-313, 2012.

doi: 10.2298/APT1243305V

[19] Abu-Bakar MF, Ismail NA, Isha A, Mei-Ling AL. Phytochemical composition and biological activities of selected wild berries (Rubus moluccanus L., R. fraxinifolius Poir, and R. alpestris Blume). Evidence-Based Complementary and Alternative Medicine, 2016: 110, 2016.

doi: $10.1155 / 2016 / 2482930$

[20] Guerrero G, Suarez M, Moreno G. Derivados hidroxicinámicos para la discriminación de genotipos de café. Cenicafé, 54 (3): 234241, 2004.

https: / / w w w.cenicafe.org/es/publications / $\operatorname{arc054\% 2803\% 29234-241.pdf~}$

[21] Calderón-Oliver M, Escalona-Buendía HB, Medina-Campos ON, Pedraza-Chaverri J, Pedroza-Islas R, Ponce-Alquicira E. Optimization of the antioxidant and antimicrobial response of the combined effect of nisin and avocado byproducts. LWT Food Science and Technology, 65: 46-52, 2016.

doi: 10.1016/j.lwt.2015.07.048

[22] Estupiñan DC, Schwartz SJ, Garzón GA. Antioxidant activity, total phenolics content, anthocyanin, and color stability of isotonic model beverages colored with Andes Berry (Rubus glaucus Benth) anthocyanin powder. Journal of Food Science, 76 (1): S26-S34, 2011.

doi: 10.1111/j.1750-3841.2010.01935.x 
[23] Fontaine BM, Nelson K, Lyles JT, Jariwala PB, GarcíaRodriguez JM, Quave CL, Weinert EE. Identification of ellagic acid rhamnoside as a bioactive component of a complex botanical extract with anti-biofilm activity. Frontiers in Microbiology, 8(MAR): 496, 2017.

doi: $10.3389 /$ fmicb.2017.00496

[24] Balasundram N, Sundram K, Samman S. Phenolic compounds in plants and agro-industrial by-products: Antioxidant activity, occurrence, and potential uses. Food Chemistry, 99 (1): 191-203, 2006.

doi: 10.1016/j.foodchem.2005.07.042

[25] Sharma OP, Bhat TK. DPPH antioxidant assay revisited. Food Chemistry, 113 (4): 1202-1205, 2009.

doi: 10.1016/j.foodchem.2008.08.008

[26] Prior RL, Wu X, Schaich K. Standardized methods for the determination of antioxidant capacity and phenolics in foods and dietary supplements. Journal of Agricultural and Food Chemistry, 53 (10): 4290-4302, 2005.

doi: $10.1021 /$ jf0502698

[27] Jones A, Pravadali-Cekic S, Dennis GR, Bashir R, Mahon PJ, Shalliker RA. Ferric reducing antioxidant potential (FRAP) of antioxidants using reaction flow chromatography. Analytica Chimica Acta, 967: 93-101, 2017.

doi: 10.1016/J.ACA.2017.02.032

[28] Vasco C, Ruales J, Kamal-Eldin A. Total phenolic compounds and antioxidant capacities of major fruits from Ecuador. Food Chemistry, 111 (4): 816-823, 2008.

doi: 10.1016/j.foodchem.2008.04.054

[29] Bernal LJ, Melo LA, Díaz Moreno C. Evaluation of the antioxidant properties and aromatic profile during maturation of the blackberry (Rubus glaucus Benth) and the bilberry (Vaccinium meridionale Swartz). Revista Facultad Nacional de Agronomía, 67 (1): 7209-7218, 2014.

doi: $10.15446 /$ rfnam. v67n1.42649 
[30] Wang SY, Lin HS. Antioxidant activity in fruits and leaves of blackberry, raspberry, and strawberry varies with cultivar and developmental stage. Journal of Agricultural and Food Chemistry, 48 (2): 140-146, 2000 .

doi: 10.1021 / jf9908345

[31] Sellappan S, Akoh CC, Krewer G. Phenolic compounds and antioxidant capacity of Georgia-grown blueberries and blackberries. Journal of Agricultural and Food Chemistry, 50 (8): 2432-2438, 2002.

doi: $10.1021 /$ jf011097r

[32] Garzón G, Riedl K., Schwartz S. Determination of anthocyanins, total phenolic content, and antioxidant activity in Andes berry (Rubus glaucus Benth). Food Science, 74 (3): C227-C232, 2009.

doi: 10.1111/j.1750-3841.2009.01092.x

[33] Zacarés L, López-Gresa MP, Fayos J, Primo J, Bellés JM, Conejero $\mathrm{V}$. Induction of $\mathrm{p}$-coumaroyldopamine and feruloyldopamine, two novel metabolites, in tomato by the bacterial pathogen Pseudomonas syringae. Molecular Plant-Microbe Interactions, 20 (11): 1439-1448, 2007.

doi: 10.1094/MPMI-20-11-1439

[34] Ribera A, Zuñiga G. Induced plant secondary metabolites for phytopathogenic fungi control: A review. Journal of Soil Science and Plant Nutrition, 12 (4): 893-911, 2012.

doi: 10.4067/S0718-95162012005000040

[35] Mikulic-Petkovsek M, Schmitzer V, Stampar F, Veberic R, Koron D. Changes in phenolic content induced by infection with Didymella applanata and Leptosphaeria coniothyrium, the causal agents of raspberry spur and cane blight. Plant Pathology, 63(1): 185-192, 2014.

doi: $10.1111 /$ ppa.12081

[36] Badhani B, Sharma N, Kakkar R. Gallic acid: a versatile antioxidant with promising therapeutic and industrial applications. RSC Advances, 5 (35): 27540-27557, 2015.

doi: 10.1039/C5RA01911G 
[37] Do QD, Angkawijaya AE, Tran-Nguyen PL, Huynh LH, Soetaredjo FE, Ismadji S, Ju YH. Effect of extraction solvent on total phenol content, total flavonoid content, and antioxidant activity of Limnophila aromatica. Journal of Food and Drug Analysis, 22 (3): 296-302, 2014.

doi: 10.1016/J.JFDA.2013.11.001

[38] Carbonel KN, Suárez-Cunza S, Arnao I. Características fisicoquímicas y capacidad antioxidante in vitro del extracto de Gentianella nitida. Anales de la Facultad de Medicina, 77 (4): 333-337, 2016.

doi: $10.15381 /$ anales. v77i4.12648

[39] Paredes-López O, Cervantes-Ceja ML, Vigna-Pérez M, Hernández-Pérez T. Berries: Improving human health and healthy aging and promoting quality life-A Review. Plant Foods for Human Nutrition, 65 (3): 299-308, 2010.

doi: $10.1007 /$ s11130-010-0177-1 


\section{Cambios en los compuestos fenólicos y capacidad antioxidante de las moras andinas en repuesta a Peronospora sparsa}

Resumen: En Colombia, la mora andina (Rubus glaucus Benth) es de gran importancia económica por su uso en la industria y amplio consumo como fruta fresca. Sin embargo, el cultivo es altamente susceptible a la enfermedad producida por Peronospora sparsa, un hongo que causa entre 50 y $70 \%$ de pérdidas en la producción. Las plantas responden al daño inducido por el patógeno incrementando la producción de metabolitos secundarios específicos, como compuestos fenólicos, que tienen amplias aplicaciones industriales. Este trabajo estimó la capacidad antioxidante y el contenido fenólico de moras andinas sanas e infectadas por Peronospora sparsa. La capacidad antioxidante fue analizada por los métodos DPPH y FRAP, mientras que los compuestos fenólicos se analizaron con cromatografía liquida de alta resolución acoplada con detección de arreglo de diodos (HPLC-DAD). Según el método DPPH, la capacidad antioxidante

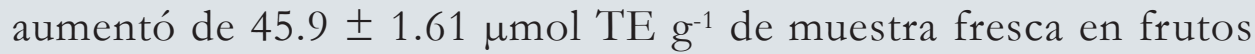
sanos a $67.02 \pm 0.58 \mu \mathrm{mol} \mathrm{TE} \mathrm{g}^{-1}$ en muestra fresca de frutos afectados. El método FRAP reveló una diferencia en la respuesta antioxidante de $5.19 \pm 0.8 \mathrm{mmol} \mathrm{TE} 100 \mathrm{~g}^{-1}$ de muestra fresca en frutos sanos vs. $10.97 \pm 0.27 \mathrm{mmol} \mathrm{TE} 100 \mathrm{~g}^{-1}$ de muestra fresca en frutos afectados. El contenido de compuestos fenólicos se observó en un rango de $4.14 \pm 1.16$ a $72.03 \pm 26.68 \mathrm{mg}$ GAE $\mathrm{L}^{-1}$ para frutos sanos y de $4.48 \pm 1.76$ a $221.89 \pm 1.18 \mathrm{mg} \mathrm{GAE} \mathrm{L} \mathrm{m}^{-1}$ para frutos afectados. Los ácidos fenólicos fueron los principales fenoles detectados, junto con derivados del ácido gálico, ácido clorogénico, ácido ferúlico, ácido elágico y ácido p-cumárico. Este trabajo confirmó que las moras infectadas con Peronospora sparsa contenían relativamente más antioxidantes y compuestos ácidos fenólicos que sus contrapartes sanas, y que esta diferencia se debió probablemente a un mecanismo de defensa para hacer frente al daño inducido por el patógeno.

Palabras clave: antioxidantes; cromatografía líquida; patógenos; ácidos fenólicos; Rubus glaucus Benth. 


\section{Mudancas nos compostos fenólicos e capacidade antioxidante das amoras andinas em resposta a Peronospora sparsa}

Resumo: A amora andina (Rubus glaucus Benth) possui grande importância econômica em Colômbia pelo seu uso na indústria e amplo consumo como fruta fresca. Entretanto, o cultivo é altamente suscetível a doença produzida por Peronospora sparsa, um fungo que causa entre 50 e $70 \%$ de perdas na produção. As plantas respondem ao dano induzido pelo patógeno aumentando a produção de metabólitos secundários específicos, como compostos fenólicos, que tem amplia aplicações industriais. Este trabalho determinou a capacidade antioxidante e o teor de compostos fenólicos de amoras andinas sadias e infectadas por Peronospora sparsa. A capacidade antioxidante foi analisada pelos métodos de DPPH e FRAP, e os compostos fenólicos se analisaram por Cromatografia Líquida de Alta Eficiência acoplada a detector de arranjo de diodos (HPLC-DAD). De acordo com os resultados de DPPH, a capacidade antioxidante aumentou de 45,9 $\pm 1,61 \mu \mathrm{mol}$ TE $\mathrm{g}^{-1}$ de amostra fresca em frutos sadios a $67,02 \pm 0,58 \mu \mathrm{mol}$ TE $\mathrm{g}^{-1} \mathrm{em}$ amostra fresca de frutos afetados. O método FRAP revelou uma diferença na resposta antioxidante de 5,19 \pm 0,8 mmol TE 100 $\mathrm{g}^{-1}$ de amostra fresca em fruto sadio contra $10,97 \pm 0,27 \mathrm{mmol}$ TE $100 \mathrm{~g}^{-1}$ de amostra fresca em frutos afetados. O teor de compostos fenólicos se observou em uma faixa de 4,14 \pm 1,16 a 72,03 $\pm 26,68$ mg GAE L-1 para frutos sadios e de 4,48 $\pm 1,76$ a $221,89 \pm 1,18$ mg GAE L ${ }^{-1}$ para frutos afetados. Os ácidos fenólicos foram os principais fenóis detectados, juntamente com derivados de ácido gálico, ácido clorogénico, ácido ferúlico, ácido elágico e ácido $p$-cumárico. Este trabalho confirmou que as amosras infectadas com Peronospora sparsa continham relativamente mais antioxidantes e compostos tipo ácidos fenólicos que suas contrapartes sadias, e que essa diferença foi devida provavelmente a um mecanismo de defesa em contra ao dano induzido pelo patógeno.

Palavras-chave: Antioxidante; cromatografia líquida; patógenos; ácidos fenólicos; Rubus glucus Benth. 


\section{Nathalia Cardona Hurtado}

Industrial Chemistry from Universidad Tecnológica de Pereira, MSc in Ecotechnology. Currently works at the Oleoquimica research group for Universidad Tecnológica de Pereira, Pereira, Colombia.

ORCID: 0000-0002-3814-4726

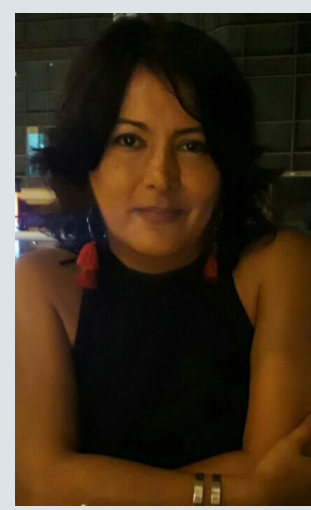

\section{Gloria E. Guerrero Álvarez}

Is professor of analytic chemestry at Universidad Tecnológica of Pereira and obtained his Doctoral degree in Chemestry at Universidad Nacional of Colombia and director of research group of Oleoquimica. His research area is comprehensive study of promising fruit trees in the Coffe Region.

ORCID: 0000-0002-0529-5835

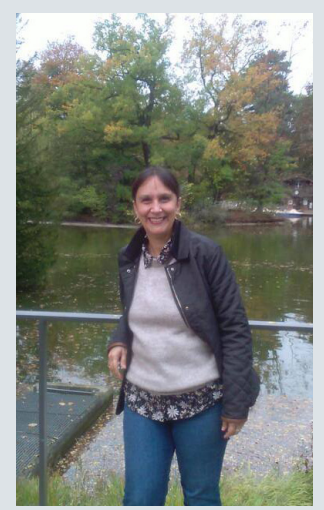

\section{Ana María López Gutiérrez}

Agronomist engineer from Universidad de Caldas in 1998, MSc in Plant Biology (2009), and PhD in Agrarian Sciences (2019). Currently works as Professor of Biology, Plant Physiology and Biochemestry at the Universidad Tecnológica de Pereira, Pereira, Colombia.

ORCID: 0000-0002-5138-1806 